\title{
Identifikasi Jenis Teripang Genus Holothuria Asal Perairan Sekitar Kepulauan Seribu Berdasarkan Perbedaan Morfologi
}

\author{
Dewi Elfidasari*, Nita Noriko, Ninditasya Wulandari, Analekta Tiara Perdana \\ Program Studi Biologi, Fakultas Sains dan Teknologi, \\ Universitas Al Azhar Indonesia, Jl. Sisingamangaraja, Jakarta 12110 \\ *Penulis untuk Korespondesi: d_elfidasari@uai.ac.id
}

\begin{abstract}
Abstrak - Teripang adalah hewan invertebrata laut yang merupakan anggota hewan berkulit duri (Echinodermata) memiliki potensi ekonomi yang cukup besar karena mengandung berbagai bahan yang bermanfaat dan dapat dijadikan sebagai sumber protein hewani, obat luka dan anti inflamasi. Eksploitasi yang terjadi secara besar-besaran dikhawatirkan akan merusak kelestarian teripang di alam. Untuk itu diperlukan informasi dasar terkait jenis dan morfologi teripang yang terdapat di perairan sekitar Kepulauan Seribu, khususnya di P. Pari dan P. Pramuka. Pengambilan sampel dilakukan pada pagi dan sore hari, yaitu pada saat kondisi surut di perairan sekitar P. Pari dan P. Pramuka. Sampel selanjutnya dikoleksi untuk diidentifikasi jenisnya berdasarkan perbedaan morfologi. Hasil analisis bentuk, warna, corak warna dan tipe spikula pada teripang tersebut menunjukan, terdapat empat jenis teripang yang berbeda berasal dari Kelas Holothuroidea, Subkelas Aspidochirotacea, Ordo Aspidochirotda, Famili Holothuriidae dan Genus Holothuria. Dua jenis yang terdapat di perairan sekitar P. Pari adalah Holothuria impatiens dan $\boldsymbol{H}$. atra, sedang dua jenis yang diperoleh dari perairan sekitar P. Pramuka adalah $\boldsymbol{H}$. edulis dan $\boldsymbol{H}$. fuscocinerea. Perbedaan jenis pada masing-masing perairan disebabkan karena perbedaan jenis habitat dan sumber bahan makanan yang terdapat di perairan tersebut.
\end{abstract}

Abstract - Sea cucumber is marine invertebrate that that member of Echinodermata (the thornskinned animals), which has considerable economic potential because it contains many useful material and can be used as source of animal protein, drug injury, and anti inflammatory. Massive exploitation is predicted destroying the existance of sea cucumbers in nature. Furthermore, basic information related with the type and morphology of sea cucumbers, especially in Pari Island and Pramuka Island is required. Sampling was carried out in the morning and the afternoon when the condition of waters around Pari Island and Pramuka Island is being low tide. The following samples were collected to identify the species based on morphological differences. The result of the analysis of shape, colour, colour shades, and type of spicules on sea cucumbers showed there are four different types of sea cucumbers from the Class Holothuroidea, Subclass Aspidochirotacea, Order Aspidochirotida, Family Holothuriidae and Genus Holothuria. Two types found in Pari Island are Holothuria impatiens and $H$. atra, whereas two types found in Pramuka Island are $H$. edulis and $H$. fuscicinerea. The diffrences in each type are caused by the difference of habitat and food source in the waters of Pari Island and Pramuka Island.

Keywords - sea cucumber, Pari Island, Pramuka Island, identification, morfology

\section{PENDAHULUAN}

Salah satu biota laut yang memiliki potensi Nekonomi adalah teripang. Nilai ekonomi penting pada teripang berasal dari tingginya kandungan atau kadar nutrisi yang tinggi yang terdapat dalam tubuh teripang.

Hasil penelitian yang telah dilakukan oleh beberapa orang menunjukan bahwa kandungan nutrisi teripang dalam kondisi kering terdiri dari protein sebanyak $82 \%$, lemak $1,7 \%$, kadar air $8,9 \%$, kadar abu $8,6 \%$, dan karbohidrat 4,8\% [1]. Teripang juga 
mengandung mineral yang cukup lengkap berupa kalsium, natrium, fosfor, kromium, mangan, zat besi, kobal, seng, dan vanadium [2].

Tingginya kadar nutrisi dalam tubuh teripang inilah yang menyebabkan terjadinya pengambilan teripang secara besar-besaran tanpa memperhatikan kelestariannya. Kecenderungan ini diduga disebabkan adanya peningkatan eksploitasi dan pengambilan teripang dari habitat alaminya dengan meningkatnya permintaan ekspor akan produk teripang di Indonesia yang diikuti dengan semakin naiknya harga di pasaran internasional [3].

Apabila hal ini dilakukan secara terus menerus tanpa adanya upaya budidaya untuk menjaga kelangsungan hidup teripang, maka dapat dipastikan sumber alam yang sangat potensial ini akan musnah. Sehingga perlu dilakukan berbagai upaya upaya untuk menjaga kelestarian teripang di perairan Indonesia antara lain dengan tersedianya data biologi terkait keberadaan teripang di perairan Indonesia. Informasi dasar yang perlu diketahui antara lain data terkait jenis dan morfologi teripang yang memiliki nilai penting ekonomis tersebut

Salah satu perairan di sekitar Indonesia, khusunya di sekitar Pulau Jawa yang memiliki populasi teripang cukup baik adalah perairan di sekitar Kepulauan Seribu. Berdasarkan beberapa hasil penelitian yang telah dilakukan, jenis-jenis teripang yang terdapat di perairan ini berasal dari famili Holothuriidea [4] dan [5]. Jenis teripang ini termasuk yang memiliki nilai ekonomis tinggi. Untuk itu perlu diperoleh data apakah jenis-jenis teripang tersebut masih terdapat di perairan di sekitar Kepulau Seribu dan bagaimana morfologi teripang tersebut.

\section{TINJAUAN PUSTAKA}

Teripang adalah salah satu anggota hewan berkulit duri (Echinodermata). Duri pada teripang sebenarnya merupakan rangka atau skelet yang tersusun dari zat kapur dan terdapat di dalam kulitnya. Rangka dari zat kapur itu tidak dapat terlihat dengan mata telanjang karena sangat kecil sehingga perlu menggunakan mikroskop. Meski demikian, tidak semua jenis teripang mempunyai duri beberapa jenis teripang tidak memiliki duri.

Terdapat sekitar 1.250 jenis teripang yang telah didiskripsikan oleh para taksonom. Teripang- teripang tersebut dibedakan dalam enam bangsa (ordo) yaitu Dendrochirotida, Aspidochirotida, Dactylochirotida, Apodida, Molpadida, dan Elasipoda. [6].

Secara taksonomi, klasisfikasi teripang [7] adalah,

$\begin{array}{ll}\text { Filum } & : \text { Echinodermata } \\ \text { Subfilum } & : \text { Echinozoa } \\ \text { Kelas } & : \text { Holothuroidea } \\ \text { Subkelas } & : \text { Aspidochirotacea } \\ \text { Ordo } & : \text { Aspidochirotida } \\ \text { Famili } & : \text { Holothuriidae } \\ \text { Genus } & : \text { Holothuria, Muelleria, Stichopus }\end{array}$

Semua jenis teripang komersil, khususnya dari daerah tropika, termasuk dalam bangsa (ordo) Aspidochirotida dari suku (family) Holothuriidae dan Stichopodidae. Meliputi genus Holothuria, Actinopyga, Bohadschia, Thelenota dan Stichopus. Terdapat 25 jenis teripang berpotensi komersil yang diidentifikasikan berasal dari perairan karang di Indonesia [6], sepuluh jenis diantaranya mempunyai nilai komersil baik (Tabel 1).

Tubuh teripang umumnya berbentuk bulat panjang atau silindris sekitar 10-30 cm, dengan mulut pada salah satu ujungnya dan anus pada ujung lainnya. Mulut teripang dikelilingi oleh tentakel atau lengan peraba yang kadang bercabang-cabang. Tubuhnya berotot, sedangkan kulitnya dapat halus atau berbintil [1].

Habitat teripang tersebar luas di lingkungan perairan di seluruh dunia, mulai dari zona pasang surut sampai laut dalam terutama di Samudra Hindia dan Samudra Pasifik Barat. Beberapa diantaranya lebih menyukai perairan dengan dasar berbatu karang, yang lainnya menyukai rumput laut atau dalam liang pasir dan lumpur. [6]. Jenis teripang yang termasuk dalam Holothuria, Scitopus dan Muelleria memiliki habitat berada di dasar berpasir halus, terletak di antara terumbu karang, dan dipengaruhi oleh pasang surut air laut. [8].

Di sekitar perairan Pulau Pari, penyebaran teripang dapat dibagi berdasarkan habitat teripang yang meliputi, daerah rataan pasir (berbatasan dengan daerah pertumbuhan alga) pada daerah ini dijumpai teripang jenis Holothuria dalam jumlah sedikit; daerah ilalang laut dan daerah pertumbuhan alga yang memiliki keragaman teripang cukup tinggi karena dijumpai jenis-jenis Holothuria scabra, $H$. arenicola, $H$. edulis, $H$. nobilis, $H$. atra dan Stichopus variegatus, dan daerah perairan dangkal 
yang memiliki jenis Holothuria atra, H. coluber, Stichopus variegatus, $S$. choloronatus dan Thelenota anana [4].

Teripang memiliki peran yang cukup penting dalam perairan, karena merupakan komponen utama dalam rantai pakan (food chain) terumbu karang dan ekosistem asosiasinya pada berbagai tingkat struktur pakan (trophic levels). Teripang berperan penting sebagai pemakan deposit (deposit feeder) dan pemakan suspensi (suspensi feeder) [9].

Dalam rantai makanan di perairan laut (marine aquatic), teripang berperan sebagai penyumbang pakan berupa telur, larva dan juwana teripang, bagi organisma laut lain seperti berbagai krustasea, moluska maupun ikan. Teripang mencerna sejumlah besar sedimen, yang memungkinkan terjadinya oksigenisasi lapisan atas sedimen [7] [8].

Tingkah laku teripang yang "mengaduk" dasar perairan dalam cara mendapatkan pakannya, membantu menyuburkan substrat disekitarnya. Keadaan ini mirip seperti dilakukan cacing tanah di darat. Proses tersebut mencegah terjadinya penumpukan busukan benda organik dan sangat mungkin membantu mengontrol populasi hama dan organisma patogen termasuk bakteri tertentu [8].
Siklus hidup sebagian besar teripang dilakukan di dasar laut dangkal dan biasanya dijumpai tergeletak pada satu sisi tertentu saja, yakni pada bagian tubuh yang biasanya berwarna lebih pucat. Ada juga jenis teripang yang sering membenamkan diri di dalam pasir. Teripang bergerak dengan sangat lambat dengan kaki tabung. Pada tiap-tiap kaki tabung terdapat 2 baris pembuluh kaki yang secara bergantian (kontraksi dan relaksasi) akan menghasilkan gerakan maju pada teripang [10].

Kebanyakan teripang bersifat nokturnal yaitu aktif mencari makan pada malam hari dan menyembunyikan diri pada siang hari. Proses makan meliputi pergerakan secara random untuk mencari makan dan memakannya secara simultan sesuai dengan kelimpahan dan keberadaan detritus. Sebagai oprganisme yang bisa bergerak dengan lambat, teripang ini sangat tergantung dengan ketersediaan pakan di substrat. Kebanyakan suplai makanan adalah bentik dan berada di bawah tubuh teripang dari pada di kolom air. Hal ini tampak pada bentuk tubuhnya di mana mulut terletak di bagian ventral [3].

Tabel 1. Jenis teripang yang terdapat di perairan Indonesia

\begin{tabular}{|c|c|c|c|c|}
\hline Famili & Ordo & Genus & Spesies & Nama daerah \\
\hline \multirow[t]{24}{*}{ Aspidochirotida } & Holothuriidae & Actinopyga & A. miliaris & Teripang lotong \\
\hline & & & A. lecanora & Teripang batu \\
\hline & & & A. echinites & Teripang batu \\
\hline & & & A. mauritiana & Teripang bilalo \\
\hline & & Holothuria & H. scabra & Teripang pasir, teripang putih \\
\hline & & & H. nobilis & Teripang susuan hitam \\
\hline & & & H. fuscogilva & Teripang susuan putih \\
\hline & & & H. atra & Teripang dada merah \\
\hline & & & H. edulis & Teripang keling \\
\hline & & & H. coluber & Teripang tali jangkar \\
\hline & & & H. leucospilota & Teripang hitam \\
\hline & & & H. pervicax & Teripang karang \\
\hline & & & H. fuscocinerea & Teripang karang \\
\hline & & & H. gyrifer & Teripang karang \\
\hline & & & H. hilla & Teripang karang \\
\hline & & & H. impatiens & Teripang karang \\
\hline & & & H. pardalis & Teripang karang \\
\hline & & Bohadschia & B. argus & Teripang mata kucing \\
\hline & & & B. graeffei & \\
\hline & & & B. marmorata & Teripang getah putih \\
\hline & Stichopodidae & Stichopus & $\begin{array}{l}\text { S. chloronotus } \\
\text { S. horrens }\end{array}$ & Teripang belimbing \\
\hline & & & S. variegates & Teripang kasur \\
\hline & & Thelenota & T. ananas & Teripang nenas \\
\hline & & & T. anax & \\
\hline
\end{tabular}


Penelitian yang dilakukan dalam [3] mengenai aktivitas makan pada teripang di Pasifik yang hidup di berbagai pulau, termasuk yang hidup di rataan terumbu karang Pulau Palao, membagi aktivitas makan teripang dalam dua kelompok, yaitu teripang yang selalu diam pada permukaan pasir dan makan setiap saat, siang dan malam hari dan teripang yang makan 2 sampai 3 kali sehari dan sisa waktunya digunakan untuk berlindung di batu karang atau menggali lubang di bawah permukaan pasir atau alga hijau.

Penelitian ini bertujuan untuk mengidentifikasi teripang yang ada di sekitar Pulau Pari dan Pulau Pramuka Kepulauan Seribu. Manfaat dari penelitian ini adalah diperoleh informasi yang dapat menjadi acuan bagi upaya budidaya teripang sebagai penunjang sumber bahan makanan alternatif khususnya protein bagi masyarakat.

\section{METODE PENELITIAN}

Objek penelitian berupa teripang yang diperoleh dari perairan di skeitar Pulau Pari dan Pulau Pramuka Kepulauan Seribu.

Identifikasi morfologi dan anatomi dilakukan di Laboratorium Biologi Makro, Departemen Manajemen Sumberdaya Perairan, Fakultas Kelautan dan Ilmu Perikanan, IPB tempat identifikasi dan analisa morfologi anatom

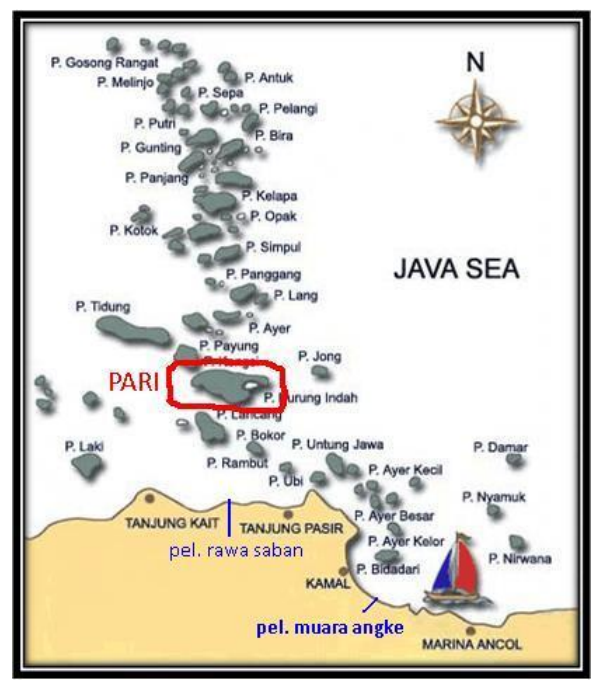

Gambar 1. Lokasi pengambilan teripang di sekitar perairan P. Pari dan P. Pramuka[11]

\subsection{Metode Pengambilan Sampel}

Sampel diambil secara acak dengan menelusuri daerah timur dan barat Pulau Pari dan daerah utara Pulau Pramuka. Pengambilan sampel dilakukan pada pagi dan sore hari pada saat air mengalami kondisi surut. Teripang yang diperoleh dimasukkan ke dalam botol koleksi dan diberi label sesuai lokasi dan waktu pengambilan.

\subsection{Identifikasi Sampel}

Sampel yang telah diperoleh dianalisis di laboratorium untuk diidentifikasi jenisnya dengan panduan dari beberapa literatur [12] [13] dan juga menggunakan program berbasis internet The Taxonomicon [14] dan ZipcodeZoo [15] untuk megidentifikasi taksonomi dari jenis teripang.

Identifikasi dilakukan berdasarkan morfologi dan warna tubuh serta spikula dari jaringan integumen dorsal. Spikula yang diamati berupa tulang-tulang mikroskopis yang terbentuk dari zat kapur yang terbenam di jaringan integumen, tentakel, papila, dan podia. Spikula diisolasi dari jaringan integumen bagian dorsal. Potongan daging teripang sebesar $1-2 \mathrm{~cm}^{2}$ direndam dalam larutan pemutih selama 10-20 menit. Larutan akan melarutkan jaringan penyusun integumen dan spikula akan akan mengendap di dasar cawan. Supernatan lalu dibuang dan spikula yang mengendap dicuci dengan akuades 2-3 kali. Kemudian spikula diamati di bawah mikroskop dengan perbesaran 10 dan 40 kali.

\section{HASIL DAN PEMBAHASAN}

Dari hasil pengambilan sampel di kawasan perairan sekitar P. Pari dan P. Pramuka secara keseluruhan diperoleh tujuh sampel teripang, lima sampel berasal dari perairan di sekitar P. Pari dan 2 sampel berasal dari perairan di sekitar P. Pramuka.

Hasil analisis morfologi sampel teripang yang diperoleh pada penelitian ini diketahui bahwa teripang yang berada di sekitar perairan Kep. Seribu terdiri dari empat spesies yang berbeda yang berasal dari satu genus (Holothuria). Dua spesies berasal dari perairan di sekitar Pulau Pari yaitu Holothuris impatiens dan H. athra dan dua spesies di sekitar Pulau Pramuka yaitu H. edulis dan $H$. fuscocinerea. 
Secara morfologi dan anatomi, masing-masing jenis teripang memiliki perbedaan. Perbedaan yang tampak secara nyata dapat dilihat langsung dari bentuk, warna dan corak warna yang dimiliki oleh teripang.

Jenis Holothuria impatiens memiliki penampang tubuh bulat, sisi ventral cenderung datar, dan lubang anus bulat. Warna tubuh adalah abu-abu dengan belang berwarna hitam di punggungnya. Tubuhnya lunak dan tipis. Tipe spikula yang ditemukan di bagian dorsal adalah tipe meja dan kancing. Teripang ini ditemukan di sela pipa besar yang permukaannya seperti batu (Gambar 2).

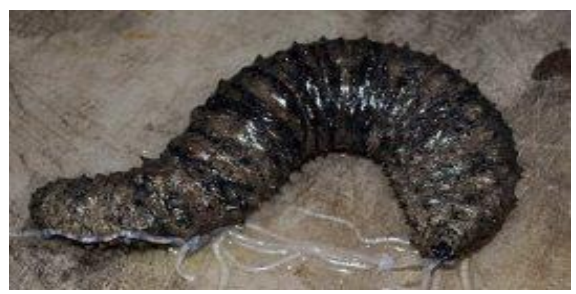

Gambar 2. H. impatiens dari perairan sekitar P. Pari

Jenis teripang lain yang juga di temukan di perairan sekitar P. Pari adalah Holothuria atra. Secara morfologi, teripang ini memiliki penampang tubuh bulat, sisi ventral yang cenderung datar, dan lubang anus yang bulat. Warna tubuh hitam kulit tubuhnya lembut dan tebal. Tipe spikula yang ditemukan di bagian dorsal adalah tipe meja, roset, dan lempeng. Ditemukan di daerah bersubstrat pasir kasar dan tubuhnya diselimuti oleh pasir halus (Gambar 3).

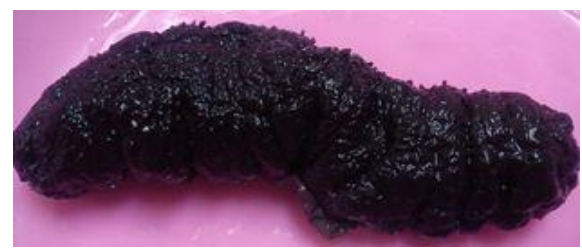

Gambar 3. H. atra dari perairan sekitar P. Pari

Jenis $H$. edulis yang dijumpai di perairan di sekitar P. pramuka secara morfologi memiliki penampang tubuh bulat, sisi ventral yang cenderung datar, dan lubang anus yang bulat. Terdapat perbedaan warna tubuh pada bagian dorsal dan ventral. Tubuh bagian dorsal berwarna hitam, sedangkan bagian ventral berwarna merah muda (Gambar 4).

Tipe spikula yang dimiliki oleh $H$. edulis yang ditemukan di bagian dorsal adalah tipe meja dan kancing sama hal seperti yang terdapat pada $H$. Impatiens. Teripang $H$. edulis ditemukan di daerah bersubstrat pasir kasar dan tubuhnya diselimuti oleh pasir halus

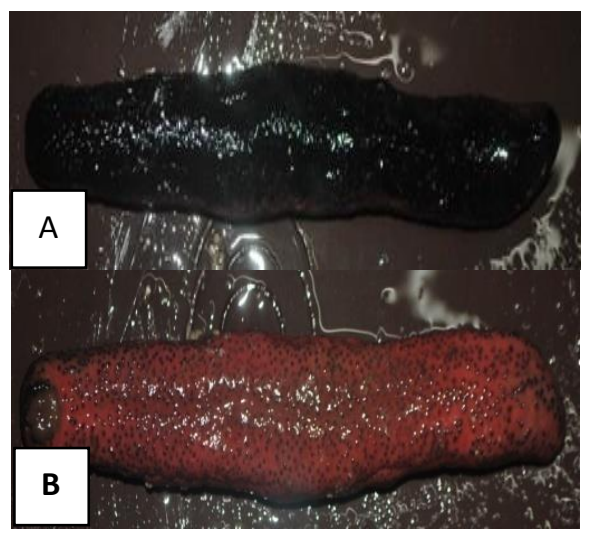

Gambar 4. Holothuria edulis dari perairan sekitar P. Pramuka (A. Dorsal; B. Ventral)

Jenis teripang lain yang dijumpai di sekitar $\mathrm{P}$. Prmauka adalah Holothuria fuscocinerea. Teripang ini secara morfologi memiliki penampang tubuh bulat, sisi ventral yang cenderung datar, dan lubang anus yang bulat. Warna tubuh bagian dorsal coklat dan bercorak, sedangkan bagian ventral berwarna coklat pucat tanpa corak. Tipe spikula yang ditemukan di bagian dorsal adalah tipe meja dan kancing. Teripang ini memiliki habitat di daerah lamun sehingga banyak dijumpai di kawasan tersebut (Gambar 5).

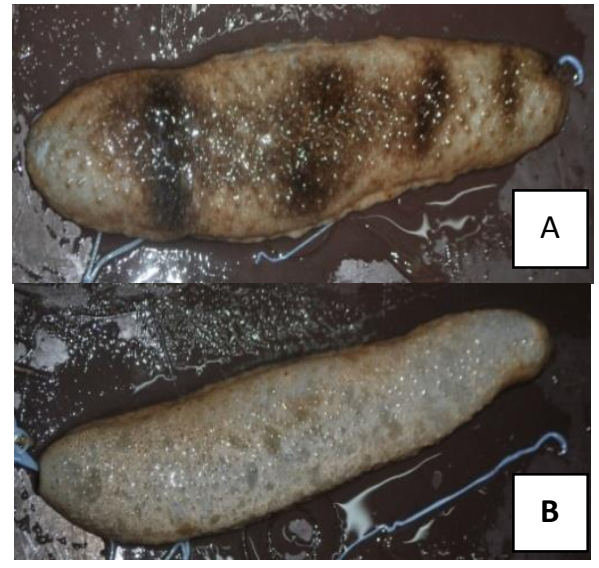

Gambar 5. Holothuria fuscocinerea dari perairan sekitar P. Pramuka (A. Dorsal; B. Ventral)

Hasil penelitian menunjukan bahwa teripang yang diperoleh dari perairan di sekitar P.Pari dan P. Pramuka berasal dari genus Holothuria dan terdiri dari empat jenis (spesies) berbeda. Keempat jenis 
teripang tersebut ditemukan pada habitat yang berbeda. Holothuria atra dan H. edulis memiliki habitat di daerah bersubstrat pasir kasar, H.impatiens ditemukan di sela pipa besar yang

permukaannya seperti batu dan $H$. fuscocinerea dijumpai pada habitat berupa padang lamun. Variasi habitat pada teripang dengan kondisi ekologis yang berbeda inilah yang akan menyebabkan perbedaan komposisi jenis, jumlah dan distribusi teripang pada setiap lokasi. Berkumpulnya teripang tertentu pada suatu habitat menunjukan bahwa keberadaan hewan ini dipengaruhi oleh tersedianya sumber bahan makanan yang terdapat pada habitat tersebut [5].

Sama seperti organisme lainnya, teripang memiliki kondisi lingkungan tertentu untuk dapat hidup dan berkembang biak pada suatu lokasi. Faktor-faktor lingkungan yang mempengaruhi keberadaan teripang meliputi salinitas, temperatur, cahaya, tekanan dan makanan [4][5][9]

Salinitas yang dibutuhkan oleh teripang genus Holothuria adalah salinitas normal $30-37 \%$ oo genus ini tidak mampu bertahan hidup pada salinitas yang rendah. Kadar salinitas yang rendah akan menyebabkan sel-sel dalam tubuh Holothuria lisis sehingga tidak mampu bertahan hidup [5][9].

Faktor berikutnya adalah temperatur lingkungan, hothuria hidup di semua kedalaman laut sehingga memiliki kemampuan toleransi pada kisaran temperature yang luas. Beberapa peneliti mencatat bahwa teripang mampu bertahan pada temperatur $25-35^{\circ} \mathrm{C}$. Lebih dari $35^{\circ} \mathrm{C}$ tubuh teripang akan mengalami inaktif akan tetapi tentakelnya masih dapat bergerak [6][9]

Cahaya juga merupakan faktor lingkungan yang berperan bagi teripang. Sebagian besar genus Holothuria bersifat nokturnal yang aktivitas hidupnya dilakukan pada malam dari atau dengan intensitas cahaya rendah. Meski demikian ada beberapa spesies yang melakukan aktivitas pada siang hari di antara terumbu karang, alga atau lamun, atau di dalam timbunan pasir. Intensitas cahaya yang tinggi akan menyebabkan pergerakan teripang menjauhi sumber cahaya, hal ini berkaitan dengan kemampuan kontraksi otot tubuh teripang [6][7][9].

Genus Holothuria dapat dijumpai pada kedalaman 0-10.750 $\mathrm{m} \mathrm{dpl,} \mathrm{hal} \mathrm{ini} \mathrm{menunjukan} \mathrm{bahwa}$ toleransi terhadap tekanan sangat besar. Genus ini mampu hidup pada beragam tekanan, akan tetapi pada beberapa genus lain tekanan akan mempengaruhi keberadaannya. Teripang yang hidup di laut dalam memiliki kisaran toleransi terhadap tekanan yang cukup kecil, beberapa genus diantaranya adalah Stichopus dan Thelenota [9][8].

Faktor utama lain yang mendukung keberadaan teripang pada suatu habitat tertentu adalah makanan. Makanan teripang berupa plankton, detritus dan kandungan zat-zat organik lain yang berada di dalam lumpur atau pasir [3]. Jenis makanan lain adalah organisme-organisme kecil, protozoa, algafilamen, rumput laut, dan potonganpotongan kecil hewan maupun tumbuhan laut serta partikel-partikel pasir [9]. Hasil penelitian menunjukan bahwa teripang menyukai habitat dengan perairan yang jernih dan aliran air relatif tenang, mereka hidup secara berkelompok [10].

Selain perbedaan habitat, penyebaran Holothuria juga dipengaruhi oleh kelimpahan makanan yang tersedia berupa plankton dan detritus. Beberapa penelitian menunjukan terdapat korelasi positif antara penyebaran beberapa jenis teripang dengan tipe habitat [3].

\section{KESIMPULAN}

Terdapat empat jenis teripang yang dijumpai di perairan sekitar P. Pari dan P. Pramuka. Jenis yang ditemukan di sekitar perairan P. Pari adalah Holothuria impatiens dan $H$. atra, sedangkan $H$. edulis dan $H$. fuscocinerea di temukan di sekitar perairan P. Pramuka.

Perbedaan setiap jenis teripang terlihat pada morfologi yang meliputi bentuk, warna, corak warna dan tipe spikula yang dimiliki masingmasing jenis teripang.

\section{UCAPAN TERIMAKASIH}

Penelitian ini mendapat bantuan dana dari Grant UAI 2011 melalui Lembaga Penelitian dan Pengabdian Masyarakat (LP2M) UAI, untuk itu kami mengucapkan terimakasih yang sebesarbesarnya atas kesempatan yang diberikan.

Terimakasih kepada Kantor Keanekaragaman Sumber Daya Alam (KSDA) Propinsi DKI Jakarta, 
Balitbang Biologi \& Puslitbang Oseanologi LIPI atas bantuannya dalam perizinan dan pengambilan sampel di P. Pari dan P. Pramuka, serta Laboratorium Biologi Mikro, Departemen Manajemen Sumberdaya Perairan, Fakultas Kelautan dan Ilmu Perikanan, IPB atas bantuannya saat analisa dan identifikasi teripang.

\section{DAFTAR PUSTAKA}

[1] J.N. Martoyo, Aji, dan T. Winanto, Budi Daya Teripang, Penebar Swadaya, Depok, 1996.

[2] M.G. Kordi. A to Z Budi Daya Biota Akuatik untuk Pangan, Kosmetik, dan Obat-Obatan, Penerbit Andi, Yogyakarta, 2010.

[3] R. Hartati, Widianingsih, dan D. Pringgienis. Skripsi Teknologi Penyediaan Pakan Bagi Teripang Putih (Holothuria scabra), Fakultas Perikanan dan Ilmu Kelautan Universitas Diponegoro, Semarang, 2005

[4] A. Aziz, Beberapa Catatan Tentang Perikanan Teripang Indonesia dan Kawasan Indo Pasifik Barat, Oseana 2:68-78, 1987.

[5] A. Aziz, dan P. Darsono, Beberapa Catatan Mengenai Fauna Ekhinodermata di Daerah Rataan Terumbu Karang Bagian Selatan Gugus Pulau Pari, Pulau-Pulau Seribu, Balitbang Biologi, Puslitbang Oseanologi LIPI, Jakarta, 1987.
[6] D. L. Pawson, Holothuroidea, In: Parker, S. P., ed. Synopsis and Classification of Living Organisms. McGraw-Hill, New York, p.813-818, 1982.

[7] J.A. Pechenik Biology of the Invertebrates, $5^{\text {th }} \mathrm{Ed}$, Mc-Graw-Hill, New York, p.503-514, 2005.

[8] P. Darsono. Teripang (Holothurians) Perlu Dilindungi. Bidang Sumberdaya Laut, Puslit Oseanografi - LIPI. Jakarta, 2005.

[9] G.J. Bakus, In: Q.A. Jones, R. Endean (Eds.) Biology and Geology of Coral Reefs, vol. II, Academic Press, New York, p.247, 1973.

[10] A.W. Radjab. Teripang di Teluk Un, Pulau Dullah Maluku Utara. Bidang Sumberdaya Laut, Puslit Oseanografi - LIPI. Jakarta, 1996.

[11] http://paradisonesia.wordpress.com/2011/04/29/pu lau-pari-the-hidden-paradise/, 2011. (Diakses pada 22 Oktober 2011)

[12] P. Purwati dan I. Wirawati, Holothuriidae (Echinodermata, Holothuridea, Aspirochirotida) Perairan Dangkal Lombok Barat Bagian I Genus Holothuria. Jurnal Oseanologi 2(1/2):1-25, 2009.

[13] P. Purwati dan A. Syahailatua (Ed) Timun Laut Lombok Barat, Ikatan Sarjana Oseanologi Indonesia (ISOI), Jakarta, 2008.

[14] Taxonomicon, http://taxonomicon.taxonomy.nl (Diakses pada 22 Oktober 2011)

[15] ZipcodeZoo, http://zipcodezoo.com/ (Diakses pada 22 Oktober 2011) 